\title{
The Role of Cognitive Conflict Approach to Improving Critical Thinking Skills and Conceptual Understanding in Mechanical Waves
}

\author{
Muh. Makhrus ${ }^{(1, *)}, Z^{2 u l ~ H i d a y a t u l l a h ~}{ }^{(2)}$ \\ ${ }^{1}$ Program Studi Pendidikan Fisika, Fakultas Keguruan dan Ilmu Pendidikan, Universitas \\ Mataram, Jl. Majapahit No.62, Gomong, Kec. Selaparang, Kota Mataram, Nusa Tenggara \\ Barat, Indonesia \\ ${ }^{2}$ Program Magister Pendidikan Fisika, Fakultas Matematika dan Ilmu Pengetahuan Alam, \\ Universitas Negeri Yogyakarta, Jl. Colombo Yogyakarta No.1, Karang Malang, \\ Caturtunggal, Kec. Depok, Kabupaten Sleman, Daerah Istimewa Yogyakarta, Indonesia
}

\begin{abstract}
Received: December 06, 2020 This study aims to determine the effect of the cognitive conflict approach Revised: January 07,2021 to critical thinking skills and conceptual understanding in mechanical Accepted: February 13, 2021 wave material. This type of research is a Pre-experimental research design with One Group Pretest-Posttest Design. The study population was all students of group 11th grade students in one of senior high school in Mataram with a sampling technique using purposive sampling. The research sample was students in all three groupses that were used as experimental groupses which were given treatment in the form of learning using the cognitive conflict approach. Instrument for critical thinking skills using student worksheet and description test. While the data of conceptual understanding was obtained by multiple choice test. Hypothesis testing in this research is a paired t-test and MANOVA test. The results of the hypothesis test give the conclusion that there is an effect of the cognitive conflict approach to critical thinking skills and conceptual understanding in mechanical wave students in the three experimental groupses. The effect in question is an increase in students' critical thinking skills from pretest to posttest.
\end{abstract}

Keywords: Cognitive conflict approach, critical thinking skills, conceptual understanding.

(*) Corresponding Author: $\quad$ Makhrus.fkip@unram.ac.id, 081353460030

How to Cite: Makhrus, M. \& Hidayatullah, Z. (2021). The role of cognitive conflict approach to improving critical thinking skills and conceptual understanding in mechanical waves. Formatif: Jurnal Ilmiah Pendidikan MIPA, 11 (1), 63-70. http://dx.doi.org/10.30998/formatif.v11i1.8142

\section{INTRODUCTION}

Learning science not only learns several theories and principles but also must analyze how to obtain facts and principles. Science does not only consist of a collection that is isolated from one another but systematically organized collection of knowledge (Hidayatullah, Makhrus, \& Gunada, 2018). Science can be seen as a process, product, and scientific attitude. Science as a product takes the form of concepts, principles, theories, and laws. Science as a process is seen as a scientific method and as an attitude that is honest, open, objective, and critical (Makhrus \& Hadiprayitno, 2012). Generally, students feel learning physics difficult because most of them has not been able to connect the concepts learned with their initial knowledge (preconception). Learners assume that what they learn has no meaning because it is not related to past events or those in their immediate surroundings. This problem will bring the mindset of students on learning that 
is very monotonous. Learning that is carried out only emphasizes students to have limited ability to answer questions. This problem will have an impact on low of conceptual understanding. Conceptual understanding is a change achieved by someone after experiencing a learning process in the form of changes in behavior, attitudes, and knowledge. Conceptual understanding is an important part of the learning process and solving problems, both in the learning process itself and in the everyday environment. Conceptual understanding becomes the basis for thinking in solving various problems (Irwandani \& Rofiah, 2015).

On the other side, along with the development of technology and information, the world of education also began to experience development. This 21 st-century education requires a high level of skills. Four skills must be possessed by students following $21 \mathrm{st}-$ century learning which is commonly abbreviated as " $4 \mathrm{C}$ ", namely critical thinking and problem-solving, creativity and innovation, communication, and collaboration (collaboration). Based on this, critical thinking is one of the main focuses of 21st-century learning. Critical thinking ability is one of the abilities expected to exist in students following the demands of 21st-century learning (Nawawi, 2017). Students should be equipped with critical thinking skills which are indispensable to compete in 21 st century life. Since people easily access to any information through the internet, critical thinking skills make people good decision makers (Abdurrahman, Setyaningsih, \& Jalmo, 2019). The exercises conducted by students influence critical thinking skills and critical thinking each student is different from one another (Fakhriyah, 2014). These critical thinking skills are not innate but appear when trained or applied through the learning process (Nurazizah, Sinaga, \& Jauhari, 2017). Critical thinking is not just about acquiring knowledge or processing skills. Critical thinking is related to the development and analysis of abilities on an ongoing basis. Critical thinking skills are needed to solve problems in real life (Walsh, Quinn, Wieman, \& Holmes, 2019).

The thinking skills students is still relatively low, especially the critical thinking skills. This is because critical thinking skills are rarely trained (Wulandari \& Nurhayati, 2018). Critical thinking skill is the skills of students to obtain detailed information so that truth is found on the information conveyed and produce conclusions objectively. Critical thinking is thinking that makes sense and is reflective of determining what decisions to believe or do (Gurcay \& Ferah, 2018; Kalelioğlu \& Gülbahar, 2014). Critical thinking is more than just the acquisition of knowledge or a collection of processing skills, but rather it is the continuous development and analysis of abilities (Arend, 2009). The critical thinking area of strategies and tactics includes essential skills needed to solve problems (Carvalho, Fiuza, Conboy, Fonseca, Santos, Gama, \& Salema, 2015). Critical thinking allows a person to assess statements, problems, provide facts, and consider various possibilities for making decisions (Danday \& Monterola, 2019).

Furthermore, improvements in learning activities need to be done so that critical thinking skills and conceptual understanding can be improved. The cognitive conflict approach is one solution to improve learning activities. Learning with the cognitive conflict allows students to express their conceptions and criticize learning that is different from their conceptions (Hidayatullah, Jumadi, Nadhiroh, Kartika, Nuha, \& Erlangga, 2020). Presentation of cognitive conflict results in students begin to compare their knowledge and experiences with the problems or knowledge conveyed by the instructor (Makhrus, 2018). Cognitive conflict is a situation in learning that makes students feel that there is information that is contradictory to their concept, so that they are interested in solving these problems to create appropriate new concepts (Chow \& Treagust, 2013). This results in students have less confidence in the truth of the preconceptions they have, and in the end, it acknowledges an anomalous situation of the problem or knowledge conveyed by the instructor with the conception possessed. Based on these problems, the 
purpose of this study was to train and improve critical thinking skills and conceptual understanding using a cognitive conflict approach. Critical thinking in this study is based on five indicators: basic clarification, basic decisions, inference, explanation, reasoning and integration. Meanwhile, conceptual understanding modified from the bloom taxonomy ( $\mathrm{C} 1$ to $\mathrm{C} 6$ : knowledge, comprehension, application, analysis, synthesis, and evaluation). Learning activities were conducted by student worksheets equipped with critical thinking tests. The aim was to practice critical thinking skills and provided assistance so that students' preconceptions can be assimilated and accommodated in the formation of new knowledge

\section{METHODS}

The type of research used is pre-experimental with pretest-posttest group design. This type of research is not yet a real experiment because there are still external variables that influence the formation of the dependent variable, not solely influenced by the independent variable (Sugiyono, 2017). The research design used is group pretest-posttest design (see Table 1). The independent variable in this study is the cognitive conflict approach, while the dependent variable is critical thinking and conceptual understanding. This research instrument was in the form of a critical thinking description test with five indicators of critical thinking from Robert $\mathrm{H}$. Ennis and a multiple-choice test according to the bloom taxonomy for conceptual understanding. The selected material was mechanical waves since this material has many misconceptions and brings students' low understanding of the material.

Table 1. Research Design

\begin{tabular}{cccc}
\hline Groups Type & Pretest & Treatment & Posttest \\
\hline 3 experimental groups & $\mathrm{O}_{1}$ & $\mathrm{X}$ & $\mathrm{O}_{2}$ \\
\hline & & & $($ Sugiyono, 2017)
\end{tabular}

The population in this study was all students of groups $11^{\text {th }}$ grade students in one of senior high school in Mataram. The total number of students in groups was 257 students divided into 6 groups. The samples of this study were students in three groups as the experimental groups. Samples were selected using a purposive sampling technique. Hypothesis testing in this study uses paired sample t-test and Manova test with SPSS 23.

\section{RESULTS \& DISCUSSION}

\section{Results}

The results of data analysis showed that there were differences in scores between pretest and posttest on critical thinking skills and conceptual understanding in mechanical wave of students in each experimental group since in each experimental groups the value of sig is obtained. (2-tailed) $<0.05$ according to Table 2 and Table 3. 
Table 2. Descriptive statistics

\begin{tabular}{ccccc}
\hline \multicolumn{1}{c}{ Skill } & Groups & Mean & $\begin{array}{c}\text { Std. } \\
\text { Deviation }\end{array}$ & N \\
\hline Critical Thinking & Cognitive Conflict 1 & 60.39 & 12.70 & 38 \\
Skills & Cognitive Conflict 2 & 53.24 & 13.70 & 34 \\
& Cognitive Conflict 3 & 65.28 & 14.85 & 35 \\
& Total & 59.72 & 14.47 & 107 \\
\hline Conceptual & Cognitive Conflict 1 & 55.96 & 11.66 & 38 \\
Understanding & Cognitive Conflict 2 & 49.61 & 8.24 & 34 \\
& Cognitive Conflict 3 & 51.24 & 9.80 & 35 \\
& Total & 52.40 & 10.34 & 107 \\
\hline
\end{tabular}

Table 3. Analysis Results of the Critical Thinking Skills and Conceptual Understanding by Paired T-Test

\begin{tabular}{lccccc}
\hline \multirow{2}{*}{ Test Type } & \multirow{2}{*}{ Groups } & \multicolumn{2}{c}{ Average Score } & \multirow{2}{*}{ df } & \multirow{2}{*}{$\begin{array}{c}\text { Sig. (2- } \\
\text { tailed) }\end{array}$} \\
\cline { 3 - 4 } & & Pretest & Posttest & & \\
Critical Thinking & Experiment 1 & 24.21 & 60.39 & 37 & 0.00 \\
Skill & Experiment 2 & 25.88 & 53.24 & 33 & 0.00 \\
& Experiment 3 & 21.00 & 65.29 & 34 & 0.00 \\
Conceptual & Experiment 1 & 25.09 & 55.96 & 37 & 0.00 \\
Understanding & Experiment 2 & 26.67 & 49.61 & 33 & 0.00 \\
& Experiment 3 & 32.19 & 51.24 & 34 & 0.00 \\
\hline
\end{tabular}

Based on the above table, it was found that the average posttest score is greater than the average pretest score on the application of the cognitive conflict approach in each experimental group. Learning with a cognitive conflict approach can confront students' thinking so that their thinking skills are trained and able to make students understand the concept through a process of demonstration or experiment, they do. The MANOVA test was used to determine whether or not there was an influence of the application of the cognitive conflict approach to critical thinking skills and conceptual understanding in mechanical waves of students at three experimental groups. Homogeneity test of variance/covariance matrix using the Box's $M$ test which is a requirement before the MANOVA test shows a significant value, so that the MANOVA test can be continued (Table 3).

Table 3. Test Homogeneity matrix variance-covariance

\begin{tabular}{ccccc}
\hline Box's M & F & df1 & df2 & Sig. \\
\hline 6.978 & 1.131 & 6 & 254615.341 & 0.341 \\
\hline
\end{tabular}

From the results, the Box's M value was 6.978 with a significance of 0.341 . Therefore, it can be concluded that the variance-covariance Matrix is homogeneous and the Manova test can be continued. The MANOVA test uses the Pillae Trace test, Wilk Lambda, Hotelling Trace, Roy's Largest Root which can be seen in Table 4.

Table 4. Multivariate Test

\begin{tabular}{ll}
\hline Effect & Sig. \\
\hline Pillai's Trace & 0.001 \\
Wilks' Lambda & 0.001 \\
Hotelling's Trace & 0.001 \\
Roy's Largest Root & 0.002 \\
\hline
\end{tabular}


From the results of the Pillae Trace, Wilk Lambda, Hotelling Trace test, which can be seen in table 4, it was found a significance of 0.001 in each test and the Roy's Largest Root test a significance of 0.002 . If a significance of 0.05 is used, it can be concluded that there is an influence of the application of the cognitive conflict approach to critical thinking skills and conceptual understanding of students in all three experimental groupses.

\section{Discussion}

The role of the cognitive conflict approach in enhancing critical thinking skills and conceptual understanding is obtained through paired t-test, but previously prerequisite tests were conducted relating to normality tests and homogeneity tests on critical thinking skills and conceptual understanding. Normality and homogeneity tests were performed on the results of the pretest and posttest. Based on the results of homogeneity and normality tests, it can be concluded that the data of critical thinking skills and conceptual understanding are included in the homogeneous and normally distributed categories so that it can be continued for hypothesis testing (paired t-test).

This paired t-test was used to determine differences in mean values before treatment and after treatment with the cognitive conflict approach. Decision-making criteria in paired t-test can be done in a way that is: if the value of sig. (2-tailed) is smaller than 0.05 , then $\mathrm{H}_{\mathrm{a}}$ is accepted (there is a difference in the average score of the posttest and pretest with the application of the cognitive conflict approach) and $\mathrm{H}_{0}$ is rejected. The average pretest score of students in each experimental group for critical thinking skills is still relatively low. The average value of students' critical thinking skills in the groups' experiment 1 was 24.21 , the groups' experiment 2 was 25.88 , and the groups' experiment 3 was 21.00. Learning with the cognitive conflict approach can improve students' critical thinking skills. This can be seen based on the increased posttest results (posttest scores are greater than pretest scores). This is following previous research which states that the cognitive conflict approach in learning physics can foster critical thinking skills (Setyowati, Subali, \& Mosik, 2011). The emergence of cognitive conflicts through problem giving and predicting answers are important points in the application of CCM because with this, educators can find out the right experimental solutions to be able to change the wrong conceptions of students. The most important thing in the cognitive conflict process is to draw attention to the state of contradiction (Kang, Scharmann, Kang, \& Noh, 2010).

Increased critical thinking skills and conceptual understanding are not optimal because the cognitive conflict approach is included in the new approach applied in those schools. The increase in value generally occurs in students who experience high cognitive conflict when learning. High cognitive conflict causes students to experience conceptual change. This conceptual change can occur after students realize the incompatibility of their initial knowledge with their scientific concepts through the learning process with the cognitive conflict approach. High cognitive conflict occurs when students become aware of anomalous or distorted states after observing demonstrations. The curiosity of students to look for scientific concepts brings students to determine the solution to the problem, or even students make it a link between the initial concepts with the newly acquired concept. Learning with cognitive conflict allows teachers to know the level of cognitive conflict in their students and allows for a conceptual change in students. This learning makes students get better understanding of scientific concepts, so they can improve their thinking ability, especially critical thinking skills. The cognitive conflict has an important role in the conceptual changes that are formed in students. Cognitive conflicts provide opportunities for students to criticize the concept and help form appropriate scientific 
concepts (Madu \& Orji, 2015). Cognitive conflict can be created through experimental or demonstration activities (Sukariasih, 2016). The most important thing in cognitive conflict is to attract students to participate in solving contradictory problems that have been prepared by the teacher (Kang, Scharmann, Kang, \& Noh, 2010).

The last test used was the MANOVA test to determine the effect of applying the cognitive conflict approach to critical thinking skills and conceptual understanding simultaneously. Critical thinking skills of students in this study were measured using a description test. Conceptual understanding is measured by multiple-choice tests based on indicators $\mathrm{C} 1$ through $\mathrm{C} 6$. The initial ability of critical thinking and conceptual understanding students in all three experimental groups is still relatively low on mechanical wave materials. It is caused by several factors such as critical thinking skills are rarely sharpened, students have not been treated with appropriate learning, and the three experimental groups have not obtained mechanical wave material according to their level. The knowledge they have is only in the form of basic knowledge about the understanding of the waves that they obtained in junior high school or that they obtained from other references and the environment. Student is naturally not a blank paper. S/he has basic knowledge from the previous education level (Schunk, 2012).

From the results of the Pillae Trace test, Wilk Lambda, Hotelling trace, see Table 4 , it can be concluded that there is an effect of applying the cognitive conflict approach to critical thinking skills and conceptual understanding in mechanical wave. The results of the pretest are known that the preconceptions (prior knowledge) of students towards a physics concept are quite varied, namely, there are between three to six kinds of students' conceptions. This shows that students enter the grouproom not with an empty head (blank mind), but they already have had a variety of ideas about natural events that are built through informal learning processes to give meaning to their daily experiences (Schunk, 2012). Learning with this cognitive conflict approach makes students feel there is a contradiction in their conception with the observed scientific concepts, so there is a conceptual change that involves the process of assimilation and accommodation. As a result of these conceptual changes, the thinking ability of students begins to increase slowly, especially critical thinking skills. Critical thinking does not increase simultaneously but needs to be practiced continuously (Hidayatullah et al., 2018; Mundilarto \& Ismoyo, 2017)

The successful use of the cognitive conflict approach is because in learning students look for their knowledge so that it will make students more active in work and thinking. The cognitive conflict has an important role in the occurrence of conceptual change. The knowledge that students get cannot be separated from the knowledge that has been previously obtained (Makhrus, Widodo, \& Agustini, 2018). Maintaining the relationship between old knowledge with knowledge that will be received by students to form new knowledge is very important. The cognitive conflict approach stimulates students to active learning. The challenges are given at the beginning of learning, such as asking students to make reasoning for predictions and estimates to explain the strategies that will be used in solving problems and they are asked to support their views. Cognitive conflict can improve conceptual understanding (Baser, 2006). Cognitive conflict approaches can be used as alternatives in learning because they can improve critical thinking skills. Students who are aware of the mismatch between scientific concepts and initial concepts try to solve the problem, thereby it leads in increasing their thinking ability. Cognitive conflict is a learning situation that makes students feels that their preconceptions are incompatible with the new knowledge being taught. This brings students to think further in solving these problems (Chow \& Treagust, 2013). 


\section{CONCLUSION}

The cognitive conflict approach plays a role in improving students' critical thinking skills and conceptual understanding of mechanical wave material. This approach is bridging students' initial concepts with the new concepts being learned. This approach also gives students the opportunity to criticize or find the truth between the initial concept and the newly learned concept by conducting experiments, seeing demonstrations, doing simulations. This approach is suitable for physics material that has many misconceptions among students. However, this approach requires good preparation in order to create a process of assimilation and accommodation during learning.

\section{REFERENCES}

Abdurrahman, A., Setyaningsih, C. A., \& Jalmo, T. (2019). Implementating multiple representation-based worksheet to develop critical thinking skills. Journal of Turkish Science Education, 16(1), 138-155. https://doi.org/10.12973/tused.10271a

Baser, M. (2006). Fostering Conceptual Change By Cognitive Conflict Based Instruction On Students' Understanding Of Heat And Temperature Concepts. Eurasia Journal of Mathematics, Science and Technology Education, 2(2), 96-114.

Carvalho, C., Fíuza, E., Conboy, J., Fonseca, J., Santos, J., Gama, A. P., \& Salema, M. H. (2015). Critical thinking, real life problems and feedback in the sciences groupsroom. Journal of Turkish Science Education, 12(2), 21-31. https://doi.org/10.12973/tused.10138a

Chow, T.-C. F., \& Treagust, D. F. (2013). An Intervention Study Using Cognitive Conflict to Foster Conceptual Change. Journal of Science and Mathematics Education in Southeast Asia, 36(1), 44-64.

Danday, B. A., \& Monterola, S. L. C. (2019). Effects Of Microteaching MultipleRepresentation Physics Lesson Study On Pre-Service Teachers' Critical Thinking. Journal of Baltic Science Education, 18(4), 692-707.

Fakhriyah, F. (2014). Penerapan problem based learning dalam upaya mengembangkan kemampuan berpikir kritis mahasiswa. Jurnal Pendidikan IPA Indonesia, 3(1), 95101. https://doi.org/10.15294/jpii.v3i1.2906

Gurcay, D., \& Ferah, H. O. (2018). High School Students' Critical Thinking Related to Their Metacognitive Self-Regulation and Physics Self-Efficacy Beliefs. Journal of Education and Training Studies, 6(4), 125. https://doi.org/10.11114/jets.v6i4.2980

Hidayatullah, Z., Jumadi, Nadhiroh, N., Kartika, E., Nuha, A. A., \& Erlangga, S. Y. (2020). Identifikasi Miskonsepsi Dan Konflik Kognitif Fisika: Kasus Terkait $\begin{array}{llll}\text { Perubahan } & \text { Konseptual. } & \text { EDUSAINS, }\end{array}$ https://doi.org/http://doi.org/10.15408/es.v12i1.13504

Hidayatullah, Z., Makhrus, M., \& Gunada, I. W. (2018). Analisis Tingkat Kemampuan Berpikir Kritis Gelombang Mekanik Melalui Pembelajaran Dengan Pendekatan Konflik Kognitif. Jurnal Pendidikan Fisika Dan Teknologi, 4(2), 151-157. https://doi.org/http://dx.doi.org/10.29303/jpft.v4i2.565

Irwandani, \& Rofiah, S. (2015). Pengaruh Model Pembelajaran Generatif Terhadap Pemahaman Konsep Fisika Pokok Bahasan Bunyi Peserta Didik MTs Al-Hikmah Bandar Lampung. Jurnal Ilmiah Pendidikan Fisika Al-Biruni, 4(2), 165-177. https://doi.org/10.24042/jpifalbiruni.v4i2.90

Kalelioğlu, F., \& Gülbahar, Y. (2014). The effect of instructional techniques on critical thinking and critical thinking dispositions in online discussion. Educational Technology and Society, 17(1), 248-258. 
Kang, H., Scharmann, L. C., Kang, S., \& Noh, T. (2010). Cognitive conflict and situational interest as factors influencing conceptual change. International Journal of Environmental and Science Education, 5(4), 383-405.

Madu, B. C., \& Orji, E. (2015). Effects of Cognitive Conflict Instructional Strategy on Students' Conceptual Change in Temperature and Heat. SAGE Open, 5(3). https://doi.org/10.1177/2158244015594662

Makhrus, M. (2018). Peranan Konflik Kognitif Terhadap Perubahan Konseptual Pada Mahasiswa Tentang Konsep Gaya. Konstan - Jurnal Fisika Dan Pendidikan Fisika, 3(1), 1-8. https://doi.org/10.20414/konstan.v3i1.1

Makhrus, M., \& Hadiprayitno, G. (2012). Penerapan Perangkat Pembelajaran Fisika Berorientasi Pembelajaran IPA Terpadu Tipe Connected. Jurnal Pendidikan Dan Pembelajaran, 19(2), 237-242.

Makhrus, M., Widodo, W., \& Agustini, R. (2018). Efektifitas Model Pembelajaran CCMCCA Untuk Memfasilitasi Perubahan Konsep Gaya Pada Mahasiswa. Jurnal Pendidikan Fisika Dan Teknologi, 4(2), 253-261. https://doi.org/10.29303/jpft.v4i2.810

Mundilarto, \& Ismoyo, H. (2017). Effect of problem-based learning on improvement physics achievement and critical thinking of senior high school student. Journal of Baltic Science Education, 16(5), 761-779.

Nawawi, S. (2017). Developing of module challenge based learning in environmental material to empower the critical thinking ability. Jurnal Inovasi Pendidikan IPA, 3(2), 212. https://doi.org/10.21831/jipi.v3i2.15988

Nurazizah, S., Sinaga, P., \& Jauhari, A. (2017). Profil Kemampuan Kognitif dan Keterampilan Berpikir Kritis Siswa SMA pada Materi Usaha dan Energi. 3, 197202. 